\title{
Assessment on Effective Implementation of Property Tax Systems in Tanzania (The Case of Dodoma Municipal Council)
}

\author{
Wakara Ibrahimu Nyabakora* Damas Okoth Hussein Ngomaitara \\ Local Government Training Institute, P. O. Box 1125, Dodoma, Tanzania
}

\begin{abstract}
The study is based on assessing the effective implementation of property tax system. It is conducted in Dodoma Municipal Council. This study specifically focus on two issues which are to analyze the extent of property tax systems implementation in Tanzania economy, and the property tax systems operating in local government Authorities in Tanzania. The study employs a cross sectional design with a case study meant to get in depth data. Respondents in this study such as property tax collectors like Dodoma Municipal staff, Ward Executive Officers, Village Executive Officers, Mtaa Executive Officers were selected by judgmental selection, and Dodoma Municipality dwellers who in this study are termed as taxpayers were randomly selected.Data gathering has done through multiple methods: interview, questionnaire and literature review. Quantitative data derived from questionnaire were analyzed by means of descriptive statistics while the qualitative data were coded, transcribed, categorized and summarized into relevant emerging themes in relation to the research questions.The findings show that property tax system in Dodoma Municipal Council is not effectively implemented because the council lack updated property register, lack of property valuation, insufficient staffs for valuation, lack of E- Taxation technology and weak property tax administration.Based on the findings, the study recommends that: The council to invest more in property tax administration, Conducting property census, Valuation of the taxable properties, Develop mechanisms to enhance tax collection, Use E-taxation systems in implementation and enforce property tax system.
\end{abstract}

Keywords: Property tax, Implementation, Tax base, Local Authority, Property Rights

DOI: $10.7176 / \mathrm{JAAS} / 61-05$

Publication date: February $29^{\text {th }} 2020$

\section{Acknowledgement}

We would like to express our heartfelt thanks and appreciation to all people who contributed in one way or another in the successful completion of this research work. We feel greatly indebted to a number of individuals that without their assistance this work would not be possible. First, we are grateful to almighty God who enabled us to successfully accomplish this study. Second, we are indebted to Dr. N. Viswanadham who was generous with his time in providing us with valuable guidance, comments and suggestions which helped in producing this report.

We are grateful to Dodoma Municipal officers specifically the Municipal Director, Accounting section department - Revenue section, Human Resources Officer, Ward executive Officers, Mtaa executive Officers, Village Executive Officers and Valuer; for accepting to provide audience for the interviews. Thanks are also due to all residents of DMC for using their valuable time to respond to the questionnaire.

Finally, we are deeply indebted to Nyabakora's family especially Mary Gasper Mahe, and their children Kasawa, Kisimba, Prosper, and Gasper; for their love and moral support. While many people have been acknowledged for helping in this work, we remain solely responsible for the shortcomings and views expressed in this paper.

\section{Introduction}

Property taxation is becoming increasingly important within the local government-financing as more and more responsibilities are being devolved from central to local governance units. This is because taxes on property are the single most important source of locally raised revenue in many parts of the world and often seen as particularly well suited as reliable revenue for local governments (McGuire, 2001; Sullivan, A. O., Sexton, T. A. \& Sheffin, S. M. 1995; Dillinger, 1992). Traditionally, property tax has been identified with the local government for reasons of its visibility and the inability of the tax object to shift location as a result of the imposed tax. The tax is also considered a suitable local source of revenue due to the linkage between the type of services often provided by local government and the enhancement in property values. Expenditure of property tax revenue on such services as fire, police protection, roads, drainage and street lighting results in increased property values within the jurisdiction.

In developing countries context, property tax is of particular importance because more responsibilities are increasingly being devolved to local government, hence the need for major local government revenue source that can generate sufficient revenue to finance local expenditure (Aluko, 2005). Taking Tanzania as an example, most urban infrastructure services developed during the colonial period and in the early years of independence 
have deteriorated due to lack of maintenance and overloading.

Recent years have witnessed local government authorities working toward improving property tax revenue performance. In Dar es Salaam for example, the need to improve property tax revenue came up in 1993, when the government was implementing the urban infrastructure programme and the need to strengthen the operational and financial viability of municipal councils became apparent. However, in Tanzanian local Governments, revenue from property tax seems to continuously keep decreasing year to year (CAG Report, 2014). Due to this decrease, the researchers have conducted the study to assess the implementation of the property tax systems in the Local Authorities as a means of revenue collection for service delivery improvement in the study area. The researchers have chosen Dodoma Municipal Council (DMC) due to the fact that, the area has both characteristics (township and rural property) that can represent the Tanzania characteristics.

However, there are many researches done internationally but, existing knowledge on International property tax practices provide limited data that can support the understanding of the property tax system of Tanzania. Data available on international experiences have application limitations because of the varying characteristics of individual property tax systems (Kayuza, 2006). Also, variations in aspects linked to property tax such as land tenure systems, property market behaviour, property tax law, availability of land information and so forth, create limitations in analyzing property tax practices given the different property tax systems. This is the essence of this research.

\subsection{Materials and Methods \\ 2.1 Materials}

\subsubsection{Views Related to Property Tax}

Economists have developed three principal views under which the incidence of property taxation has been considered. Importantly, each view distinguishes between taxes on land and taxes on capital. The observation that a property tax may have a differential effect on land as opposed to other forms of capital results from the difference in elasticity of the supply of each item. Based on the assumption that the supply of land subject to taxation in a given jurisdiction is fixed, the 'Traditional View' suggests that taxes on land will be borne by the users of land, that is, the owners or renters of the land (Netzer, 1966). The 'New View,' however, concludes that a local tax on land can be broken into two components, a 'profits tax' and an 'excise tax' (Mieszkowski, 1972b; Aaron 1975). Because the profits tax component is equivalent to a general tax on all capital, that portion of any property tax will fall on the owners' capital.

Finally, the 'Benefit View' suggests that property taxes are appropriately viewed as a user charge for local public services (Hamilton, 1975b, 1976b; Fischel, 1985, 1992). Because consumers of public services are mobile, the benefit view suggests that a property tax is in many situations is an efficient financing mechanism for public services.

\subsubsection{Ability to Pay Theory by Musgrave (1976)}

The ability-to-pay approach treats government revenue and expenditures separately. Taxes are based on taxpayers' ability to pay; there is no quid pro quo. Taxes paid are seen as a sacrifice by taxpayers who raise the issues of what the sacrifice of each taxpayer should be and how it should be measured:

- Equal sacrifice: The total loss of utility as a result of taxation should be equal for all taxpayers (the rich will be taxed more heavily than the poor)

- Equal proportional sacrifice: The proportional loss of utility as a result of taxation should be equal for all taxpayers

- Equal marginal sacrifice: The instantaneous loss of utility (as measured by the derivative of the utility function) as a result of taxation should be equal for all taxpayers. This will entail the least aggregate sacrifice (the total sacrifice will be the least)

\subsubsection{Implementation of Property Tax Systems}

The study conducted by Yiyi Xu (2011) on Property Tax Reform in China, suggested that several different real estate valuations shall be used to different properties according to different characters of the valuation methods. Moreover, combining the comparable method with mass appraisal and trying to find out the comparative set of properties and recognizing the key variables are recommended.

Bird and Slack (2002), in their study on the Review of Land and Property Taxation commented that, successful implementation of property tax reform requires a number of preconditions. One of the most important preconditions is the existence of a strong tax administration, including a process for property identification, assessment, collection, and enforcement.

De Cesare, (2002) conducted a research on 'toward More Effective Property Tax Systems in Latin America saw that learning how to implement tax reforms essential for pursuing more effective property tax systems. A trend toward using a participatory approach when undertaking such revisions is also evident, since public acceptance is likely to facilitate the reform process.

Kitchen, (2003) in his study on property tax issues in implementation in Russia suggested that, 'it is 
apparent that the most efficient, uniform, accountable and transparent municipal property tax systems around the world exist where the following conditions are met; All taxable properties are identified, described and recorded on the assessment Roll, Assessment is updated as frequently as possible, ideally on an annual basis, so that the tax base is current, uniform, consistent and fair'.

UN-HABITAT, (2011) suggested that, Tanzania must continue need for tax reforms to support local authorities in realizing their revenue potential and enhancing their service delivery capacity. The areas to be targeted for reform should be creation of good database through use of Information System and mapping of developments, improved technology like computer aided mass approval should be encouraged.

FAO Corporate Document Repository, (2013) while studying rural property tax systems in central and Eastern Europe suggest that, the difficulties of implementation should not be under-estimated. Although the technical difficulties can be overcome, they can restrict progress, especially in the early stages of implementation.

Also Kelly, (2000) suggested that, countries must undertake strategic reform, combine policy and administrative interactions to improve tax base coverage, property valuations, collection, enforcement and taxpayers' services. The tax policy reform must adjust tax base definitions and tax rate structures along with making appropriate policy decisions linked to valuation standards, appeals, collection and enforcement.

The proactive approach is also required to initially build a tax registry, update a tax registry, after a period of no maintenance or when conducting a major property valuation assessment, simple field based procedures accompanied by appropriate technology are to be used UN-HABITAT, (2011).

Machievelli, in the $16^{\text {th }}$ century noted that;

“....... there is nothing more difficult to carry out, no more doubtful of success, no more dangerous to

handle, than to initiate order of things. For the reformer has enemies in all those who profit by the old order and only lukewarm defenders in all those who would profit by the new order, this luke warmness arising partly from fear of their adversaries, who have the laws in their favour, and partly from incredulity of mankind, who do not truly believe in anything new until they have had the actual experience of it"

\subsection{Research Methods}

The study used both qualitative and quantitative research methods while employing analytical cross-sectional survey design to collect data on relevant variables as it employs exploratory, survey, and case study strategies. The exploratory study have been undertaken through discussion with Ward Executive Officers (WEOs), Village Executive Officers (VEOs), Mtaa Executive Officers (MEOs) and other community leaders in different areas of Dodoma Municipality, trying to clarify understanding of the problem. Survey mainly used questionnaire in order to collect large amount of information from sizable population. Bazeley asserts that, mixed methods research has regained not just acceptability, but popularity, with a significant number of studies arguing its virtues in terms of greater understanding and/or validation of results (2004).

Sampling involves probabilistic and non-probabilistic sampling. Purposive sampling is used to get data from Ward Executive Officers, Mtaa Executive Officers, Village Executive Officers and Dodoma Municipal Council staff. Simple random sampling is used to collect primary data from taxpayers at DMC planned streets like Kisasa, Area D, Area A, Area C, Area E, Uzunguni, Nkuhungu, Uhindini and Makole; and street corner polls as non probabilistic sampling enabled the researcher to interview even those owners of unplanned buildings of Chang'ombe, Chamwino, Chinangali west, Ipagala, Iringa road, Swaswa, Kikuyu and Nzuguni.

Sample size refers to the number of items to be selected from the population to constitute a sample. The size of the sample should neither be excessively large, nor too small. It should be optimum. An optimum sample is the one which fulfils the requirements of efficiency, representativeness, reliability and flexibility (Kothari, 2004). A sample of one hundred and thirty (130) respondents was involved in this study. This sample is obtained through the use of the following fomular; $n=Z^{2} . p q / d^{2}$

where $n$ is the sample size, $\mathrm{Z}$ is the standard variate which is 1.96 for a $95 \%$ confidence level, $\mathrm{p}$ is the proportion in the largest population which is $50 \%, \mathrm{q}$ is $1-\mathrm{p}$ and $\mathrm{d}$ is the degree of accuracy, set at 0.05 . Then, $\mathrm{n}=$ $(1.96)^{2} \times(0.5 \times 0.5) /(0.05)^{2}=384$. A larger sample could be ample but due to resources constraints, 130 respondents are covered. According to Moser and Kalton (1971), one must accept the limitations imposed by the researcher due to shortage of resources and try to utilize the available sample to the best advantage.

The sample has been analysed as shown in table 3.1 below. 
Table 1: Respondent's Categories, Sample Size and Sampling Techniques

\begin{tabular}{|l|l|l|l|l|}
\hline S/N & Category of Respondents & Sample Size & Sampling Techniques & Data Collection Method \\
\hline 1 & Dodoma Municipal staff & 5 & Purposive & Sampling \\
\cline { 1 - 2 } 2 & Village and Mtaa Executive Officers & 15 & & \\
\hline 3 & Ward Executive Officers & 10 & Random sampling & Survey questionnaire \\
\hline 4 & House owners in the Municipal & 100 & & \\
\hline & Total & $\mathbf{1 3 0}$ & & \\
\cline { 1 - 2 }
\end{tabular}

Source: Field data

The study employed qualitative and quantitative data analysis techniques. This analysis was based on the data and information collected from the field. The main beneficial aspect is that it provides the means to separate out the large number of confounding factors that often obscure the main qualitative findings (Abeyasekera, 2009). Quantitative data collected was validated and edited, Coded, cleaned, tabulated, and analyzed by using statistical package for social sciences (SPSS). While qualitative analysis was employed for qualitative data only to convince arguments to supplement quantitative data analysis.

\subsection{Results and Discussion of Findings}

\subsection{Assessment of Effective Implementation of Property Tax system in Dodoma Municipal Council}

The first research objective was to assess effective implementation of property tax system in Tanzania. The associated research questions were; to what extent the property tax system implementation is? What property tax system operates in Local Authorities in Tanzania?

From interview with Dodoma Municipal officials the findings show that implementation of property taxation in Dodoma Municipal Council involves three interrelated items: property identification, property valuation and assessment, and property tax collection. The property identification is presented first.

\subsubsection{Property Identification}

During interview with senior municipal officials, it was indicated that property identification is the first approach in the administration of property taxation. The informant claimed that the property identification provides database for estimation of revenue from property tax. Emphasizing the importance of property identification the Municipal Treasurer had the following to say:

“... Identification of taxable properties goes with property registration. This is the most important step in administration of property taxes in that the municipal council may use the property register to set a tax rates in flat rate base. This allows the municipal council to continue charging property tax in flat rates until when the properties will be valued".

Source: Interview with Municipal staff

Also, DMC revenue accountant while answering some of interview guide questions, said:

“..... The Municipal is expecting to start property identification and so valuation of four wards among seventeen wards due to limitation of resources. This could help not guessing on how much to be paid by property owners as now doing. She added that, even that guessing rates are fixed by the certain board and given to WEOs, MEOs and VEOs to implement".

Source: Interview with DMC Staff

When the researcher asked if the Municipal had the updated property register, the interviewee responded; "....... all municipal registers are with VEOs and MEOs which also are outdated and manually recorded".

Source: Interview with DMC Staff

The revenue accountants' words were supported by the questionnaire respondents as follows:

Table 2: Valuation of Property

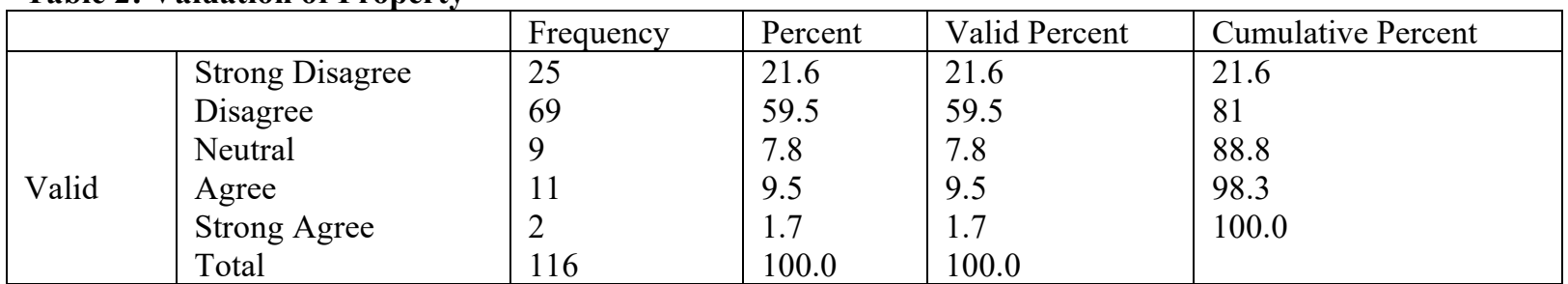

Source: Field data

The data in the table above indicates that, 94 respondents $(81 \%)$ proved that no property valuation was made in DMC in the near past, 9 respondents $(1.7 \%)$ were not aware while 13 respondents $(11.2 \%)$ said there was property valuation in DMC at the near past. The finding revealed poor property tax administration and guessing in property tax rates setting which is the crucial factor to property tax revenue decrease year to year. Moreover, the finding is consistent with Bahl' (1998) who suggests that, the effectiveness of property taxation 
relies on the capacity to identify taxable properties. Emphasizing the importance of property identification Slack (2001) commented that 'lack of Property information simply signify the lack of efficient in property tax administration'. Property identification includes the physical addresses of property owners and important in the accurate number of properties available; hence, it simplifies revenue estimation from property tax and therefore it simplifies the exercise of tax collection.

\subsubsection{Valuation and Assessments of Properties}

During interview with municipal officers, it was revealed that valuation and assessment of properties were the other processes in property tax implementation in the study area. The valuation of properties is supposed to be carried out by the qualified valuers to establish the value of the properties from which the tax is assessed. The informants added that valuation and assessment of properties provides a base for setting balanced taxes so that properties of high value are to be charged higher than properties of less value. The findings suggest that the municipal council is aware of the importance of valuation of properties; though when asked whether the valuation of properties have been carried out, they commented that the exercise was carried in the past fifteen years covering only four areas: Hazina, Area C, Area D and Kilimani. The reasons provided for this little coverage were the lack of fund for valuation exercise and few property valuers. Emphasizing the importance of property valuation the Municipal valuer had the following to say:

"...In fact, valuation of properties is important. The laws require us to value properties before we introduce taxes. But we have not been able to do it. It requires millions of money to accomplish the exercise. We tried to do it in few places in the past fifteen years as my colleague have said (pointing to his colleague)but recently we have not managed to conduct it. The council has just set flat rates which range between twenty thousand for residential house, twenty five thousand for both residential and commercial house, and thirty thousand for commercial house, one million for institutions, Fuel stations and hotels only as you can see in here (pointing to sections in council by law). However these amounts differ depending to the location of the buildings, there are places we charge even little for example un-surveyed places and in villages we normally charge five thousand only for both commercial and residential houses".

Source: Interview with DMC Staff

Questionnaire data supported the above findings whereby $81.1 \%$ of the respondents suggested that the amount they paid as a property tax did not reflect the value of their properties as there is no property valuation done in the near past, which result to, the buildings of different value in the same locality were charged similar amount of taxes.

Table 3: Valuation of Property

\begin{tabular}{|c|c|c|c|c|c|}
\hline & & Frequency & Percent & Valid Percent & Cumulative Percent \\
\hline \multirow{6}{*}{ Valid } & Strong Disagree & 25 & 21.6 & 21.6 & 21.6 \\
\hline & Disagree & 69 & 59.5 & 59.5 & 81 \\
\hline & Neutral & 9 & 7.8 & 7.8 & 88.8 \\
\hline & Agree & 11 & 9.5 & 9.5 & 98.3 \\
\hline & Strong Agree & 2 & 1.7 & 1.7 & 100.0 \\
\hline & Total & 116 & 100.0 & 100.0 & \\
\hline
\end{tabular}

\section{Source: Field data}

The findings suggest that the DMC charge flat rates because of lack of capacities to assess all properties available in its jurisdictions. The findings further suggest that the property taxation system in DMC did not provide fairness to taxpayers and that the flat rates charged is contrary to the Urban Authorities (Rating) Act No.2 of 1983 which requires the taxing authority to levy property tax based on the value of a property. The findings are consistent with Kayuza (2006) who suggested that a flat tax rate does not provide fairness to tax payers. Emphasizing the importance of property valuation Kayuza commented that 'It is quite common to find properties of different sizes and qualities are subjected to a threshold paying same taxes. Such inequitable tax liability becomes obvious to the taxpayers especially those living within the same neighborhood in that they make comparison of their properties in terms of size and quality. A property owner with an inferior property would feel being overcharged if he or she is to pay same amount of tax like a neighbor who owns a comparatively superior property. Also, the one owns the high quality property may feel undercharged, so create unfair environment.

\subsubsection{Property Tax Collection}

The interview data indicates that, property tax collection is the third next important item in property tax implementation after the identification and valuation of properties. One of the highly ranked municipal officer commented that the property identification and property valuation are the preparatory functions for efficient property tax collection. Explaining the administration of tax collection the Municipal Director contributed that, the exercise involves tax billing and a lot of follow-up and advertisement to remind taxpayers to pay taxes on time. The findings suggest that property tax collection is a tiresome exercise. It requires a sufficient number of 
staffs to accomplish the tasks involved in collection. When asked how the municipal council managed to collect property tax, one of the municipal officers commented that the collection of property taxes was done by using local government own staff at the Mtaa level where MEOs collects taxes in the area of their work. At Municipal village level, VEOs collect taxes at their respective areas and at headquarter where revenue accountant collects taxes.

The interview with WEOs, MEOs and VEOs, revealed that, tax is collected and deposited once a week; mainly at the end of the week. Then the bank slip is submitted to Municipal cashier. In answering the interview question, they explained that, they get the motivation of $5 \%$ of what everyone collect. One of them added that, they have challenges of security while they have the collected amounts.

However, the collection of property tax by using local government staffs may be limited by a number of factors: first, cost of collection may increase since the local government staffs will require to be motivated. Second, where there is no facilities such as transportation local government staffs may not make follow ups to tax payers located in a far places hence taxes will not be collected. Third, where the MEOs and VEOs have other administrative responsibilities, may lack time to make follow up for collection of taxes from payers (Rwechungura, 2000). Moreover, the interviewed MEO claimed:

"...Property tax collection is a very tedious work, but it has been left to us (Mtaa Executive Officers and Village Executive Officers). We collect and submit all the money to municipality but there is no any kind motivation. The by-laws provides that $20 \%$ of all collection will be returned to our office to facilitate us including motivation, but five years have passed since I was employed I have never seen the municipal council giving us the $20 \%$ which we are required to get. The situation is discouraging the collection of taxes. Some of our colleague tends to forge receipts to get money something which is not good".

Source: Interview with DMC MEOs

The above discussion also was supported by respondents by questionnaire where $55.2 \%$ suggested that, there was no simple and efficient method of property tax payment as shown in the table below.

Table 4: Simple and Efficient Method of Property Tax Payment

\begin{tabular}{|l|l|l|l|l|}
\hline & Frequency & Percent & Valid Percent & Cumulative percent \\
\hline Strong Disagree & 10 & 8.6 & 8.6 & 8.6 \\
Disagree & 54 & 46.6 & 46.6 & 55.2 \\
Neutral & 10 & 8.6 & 8.6 & 63.8 \\
Agree & 33 & 28.4 & 28.4 & 92.2 \\
Strong Agree & 9 & 7.8 & 7.8 & 100.0 \\
Total & 116 & 100.0 & 100.0 & \\
\hline
\end{tabular}

Source: Field data

\subsection{The Extent of Property Tax system Implementation in Dodoma}

The second objective of the study was to examine the extent to which property tax is implemented in Dodoma. With respect to this objective the associated research question was how effective is property taxation in DMC? The assessment was done based on the conceptual framework and the associated indicators set out in figure 1 of Appendix i. The conceptual framework in this study suggested that effectiveness of property taxation is assessed based on four variables namely operational capacity of the municipal council to implement property tax, supportive policy environment, tax compliance and trends of property tax collection.

\subsection{Assessment on the Property Tax System Operating in Dodoma}

The system operating in the LGAs results in good or bad performance in revenue collection as the sign forced the researcher to conduct this study. The researcher perceived the ineffective system implementation. The questionnaire finding revealed that $41.4 \%$ of respondents proved that property tax revenue does not grow year to year while leaving $21.6 \%$ not aware on the issue.

Table 5: Property Tax Revenue Growth

\begin{tabular}{|l|l|l|l|l|l|}
\hline \multicolumn{2}{|c|}{} & Frequency & Percent & Valid Percent & Cumulative Percent \\
\hline \multirow{5}{*}{ Valid } & Strongly disagree & 2 & 1.7 & 1.7 & 1.7 \\
\cline { 2 - 6 } & Disagree & 46 & 39.7 & 39.7 & 41.4 \\
\cline { 2 - 6 } & Neutral & 25 & 21.6 & 21.6 & 62.9 \\
\cline { 2 - 6 } & Agree & 38 & 32.8 & 32.8 & 95.7 \\
\cline { 2 - 6 } & Strongly agree & 5 & 4.3 & 4.3 & 100.0 \\
\cline { 2 - 6 } & Total & 116 & 100.0 & 100.0 & \\
\hline
\end{tabular}

Source: Field data

The findings revealed that the property tax revenue decreases year to year. This was caused by a number of 
factors which caused by the system prevailing one of which is the use of manual system of property tax implementation. By using manual system in property tax administration, DMC leaves the gap to revenue collectors to collude themselves and taxpayers so misappropriate the money. This is due to property registers stay with MEOs, VEOs and WEOs only and not DMC offices.

Table 6: DMC Use of Computerised Program in Property Tax Implementation

\begin{tabular}{|l|l|l|l|l|l|}
\hline \multicolumn{2}{|c|}{} & Frequency & Percent & Valid Percent & Cumulative Percent \\
\hline \multirow{5}{*}{ Valid } & Strongly disagree & 8 & 6.9 & 6.9 & 6.9 \\
\cline { 2 - 6 } & Disagree & 60 & 51.7 & 51.7 & 58.6 \\
\cline { 2 - 6 } & Neutral & 30 & 25.9 & 25.9 & 84.5 \\
\cline { 2 - 6 } & Agree & 12 & 10.3 & 10.3 & 94.8 \\
\cline { 2 - 6 } & Strongly Agree & 6 & 5.2 & 5.2 & 100.0 \\
\cline { 2 - 6 } & Total & 116 & 100.0 & 100.0 & \\
\hline
\end{tabular}

\section{Source: Field data}

The findings revealed that DMC does not use computerized system in property tax system. Eighteen respondents $(15.5 \%)$ agree that the council use computer programmes in property tax implementation. Thirty respondents $(25.9 \%)$ were not aware and sixty eight respondents $(58.6 \%)$ proved that DMC does not use computer programmes in property tax administration.

This means, using manual property tax administration system was one of factors contribute to continuous decrease of property tax revenue year to year. The statement was supported by UN - HABITAT, 2011.

\section{Conclusion}

The study specifically focused on assessing effective implementation of property tax system in Dodoma Municipal Council. A case study research design was applied, employing both primary and secondary data collection methods in order to achieve the above mentioned objectives.

Data collected were analysed by using various statistical techniques and presented in tables, frequency distribution and percentages. The qualitative data were also edited, coded and presented using direct quotation. From the analysis of data collected, the following are the findings of the study:

With regards to the implementation of property tax system in DMC, the findings revealed that the process involves property identification, valuation, assessment and tax collection. On the part of identification of taxable properties and collection of taxes the findings bared that to a large extent, it was a role of MEOs, VEOs and WEOs. Meanwhile the valuation and assessment of taxable properties was considered important in that it helped to identify the value of properties from which the tax was assessed but findings show that valuation in DMC was not done. The findings showed that lack of fund for valuation exercise made the council to adopt the flat tax rates.

With respect to second objective which aimed to assess the level of property tax system implementation, the study found that in the study area, there were no updated property tax registers to provide information on the number of available taxable properties as well as the physical address for property owners. On the case of ability to enforce property taxation, the study found that the council had insufficient staffs for valuation as well as for collection of property taxes. Furthermore, the study found that property tax contributes more than a quarter of the DMC's annual budget.

The study revealed that, DMC has bylaws and regulations on the property tax system implementation though many of them do not function; this is due to DMC leave unused the law of 'no one can sell the property if not channeled to DMC'. DMC use taxable properties to identify the property records in the outdated register.

The study aimed at assessing property tax system operating in DMC. The findings from the interviewed respondents and questionnaire revealed that, DMC use manual system and not computerized system, bylaws recognize the use of mass valuation system in property valuation though the Municipal does not assess and value the taxable properties. All the above discrepancies make the property tax revenue to decrease year to year. In general, DMC has not effectively implemented the property tax system.

\section{References}

Aaron, Henry J. (1975), “Who Pays the Property Tax? A New View”, Washington, Brookings Institution. Abeyasekera, (2009) "Quantitative Analysis Approaches to Qualitative Data". Reading RG6 6EN:Statistical Services Centre, University of Reading

Aluko, B. T. (2005) "Building Urban Local Governance Fiscal Autonomy through Property Taxation Financing Option”. Ile Ife, Nigeria. International Journal of Strategic Property Management: Obafemi Owolowo University.

Bahl, R. (1998). "Practice of Urban Property Taxation in Less Developed Countries. Cambridge": The University of Wisconsin Press.

CAG report, (2014), Performance Audit on the Revenue Collection in LGAs (Unpublished)

De Cesare, Claudia (2002), "Improving the Performance of the Property Tax in Latin America", Cambridge, 
Lincoln Institute of Land Policy.

Dick Netzer, (1966), “Economics of the Property Tax”. Washington D.C, The Brookings Institution.

Dillinger, (1992), "Property Taxes”: World Bank Publishers

FAO, (2013) “Rural Property Tax Systems in Central and Eastern Europe”. Document Repository

Fischel, W. A. (1985), "The Economics of Zoning Laws”: A Property Rights Approach to American Land Use Controls, Baltimore: MD, John Hopkins University Press.

Fischel, W. A. (1992), "Property Taxation and the Tiebout Model: Evidence for the Benefit View from Zoning and Voting”, 30 Journal of Economic Literature.

Hamilton, Bruce W. (1975b), "Zoning and Property Taxation in a System of Local Governments", 12 Urban Studies, 205-211.

Hamilton, B. W. (1976b), “Capitalization of Intrajurisdictional Differences in Local Tax Prices”, 66 American Economic Review.

Kamuzora, F. and Adam, J. (2008). "Research Methods for Business and Social Studies”. Mzumbe Book Project, Morogoro.

Kayuza, H. M (2006), "Real Property Taxation in Tanzania: An Investigation on Implementation and Taxpayer Perceptions", Doctoral Thesis Building and Real Estate Economics, Stockholm: Royal Institute of Technology, Sweden.

Kelly, R (2000), "Property Tax in East Africa. The Tale of Three Reforms", Development Discussion Paper

Kitchen, Harry M. and Enid Slack. (2003), “Business Property Taxation”, Discussion Paper No. 93 - 24, Government and Competitiveness Project, School of Policy Studies: Kingston: Queen's University.

Kothari, C. (2004), "Research Methodology, Methods and Techniques", New Delhi

McGuire, T. J. (2001). "Alternatives to Property Taxation for Local Government", in W. E. Oares (ed), Property Taxation and Local Government Finance. Essays in Honour of C. Lowell Harris, Cambridge, Massachusetts: Lincoln Institute of Land Policy.

Mieszkowski, Peter (1972b), "The Property Tax: An Excise or Profits Tax”, 1 Journal of Public Economics , 7396

Moser, C.A and Kalton, G. (1971) "Survey Methods in Social Investigation”, Gower, Aldershot.

Richard A. Musgrave \& Peggy B. Musgrave (1976), "Public Finance in Theory and Practice", $2{ }^{\text {nd }}$ Edition, New York: Mc Graw Hill

Richard M. Bird and Enid Slack, (2002), "Land and Property Taxation around the World: A Review". Journal of Property Tax Assessment and Administration. 7 (3)

Rwechungura, (2000), "Property Tax in Tanzania: An Examination Property Taxation in," in World Bank, Major Property Tax Issues in Africa, Papers from Regional seminar organized by Municipal Development Programme for Eastern and Southern Africa, 1995

Slack E, (2001), "Understanding the Evaluation of Property Tax Policy", Paper

Presented for Property Tax Odyssey 34 ${ }^{\text {th }}$ Annual National Workshop. Canadian Property Tax Inc. Ontario, 2001.

Sullivan, A. O., Sexton, T. A. \& Sheffin, S. M. (1995). Property Taxes and Tax Revolts.

Cambridge: University Press

URT/MRALG (1983), "Urban Authority Act No. 2 of 1983

URT (2002), "History of the Local Government in Tanzania”, Dar es salaam: Government printers

UN-HABITAT, (2011), "Land and Property Tax", A Policy Guide, Nairobi: United Nations, Human Settlement Programme, Vol. 978-92-1-132375-7, UNON, Publishing Services Section, Nairobi

Yiyi Xu (2011), Property Tax Reform in China 